\title{
Organizational Challenges of Online Customer Co-Creation for Innovation: A Middle-Managers' Perspective in the Italian Food Context
}

\author{
Carla Rossi ${ }^{1}$ \\ ${ }^{1}$ University of Basilicata, Potenza, Italy \\ Correspondence: Carla Rossi, DiMIE, University of Basilicata, Potenza, Italy. E-mail: carla.rossi@unibas.it
}

Received: January 15, 2021 Accepted: February 18, 2020 Online Published: February 22, 2021

doi:10.5539/ijms.v13n1p42

URL: https://doi.org/10.5539/ijms.v13n1p42

\begin{abstract}
In a nutshell, co-creation is described as a way to open up a company to the outside world, helping to generate product innovations and to update brand meanings. Drawing on the online community and co-creation literature, this paper aims at contributing to exploring the main intra-organizational challenges of online customer co-creation for innovation, from the viewpoint of middle managers. The intent is to broaden the existing conceptual understanding of the main internal factors hindering customer co-creation but also of the practices that could be adopted to best manage the related challenges.

The study adopts a qualitative approach and is based on the results of eight in-depth, semi-structured interviews with digital and marketing managers, working closely with co-creation initiatives in the Italian food industry, with the aim of exploring intra-organizational challenges perceived by those who are directly involved in co-creation implementation.

The results complement existing literature by 1) offering a more longitudinal vision of the implementation process - and the related internal hurdles, 2) identifying the most appropriate coping strategies and 3) formulating some hypothesis that could support an interpretative model of the capabilities needed to start the process and managing it in a strategic perspective.
\end{abstract}

Keywords: online customer co-creation, organizational challenges, barriers to online co-creation, collaborative marketing and innovation

\section{Introduction}

Traditionally considered as a product-taker (the "target" of the marketing actions put in place by the company), the consumer growingly assumes, in the current competitive landscape, the role of value co-creator (Prahalad \& Ramaswamy, 2000, 2004; Hatch \& Schultz, 2010; Ind, Iglesias, \& Schultz, 2013). Today's consumer possesses assets that have predominantly intangible content (time, skills, emotions, etc.) and can take on the role of business partner, by carrying out an immaterial work (Cova \& Dalli, 2007), which has a growing importance in a world where products and brands value is increasingly based on emotional contents (affectivity, shared passions, relationships, etc.) and on the ability to communicate and produce signs and symbols.

Over the past years, a vast stream of literature on co-creation flourished, mostly studying the interactions between companies and their customers from the customer perspective (Ind et al., 2013), particularly focusing on customer motivations (e.g., Füller, Mühlbacher, Matzler, \& Jawecki, 2009; Ind et al., 2013; Guzel, Sezen, \& Alniacik, 2020), resources (e.g., Arnould, Price, \& Malshe, 2006; Bonnemaizon, Benoît-Moreau, Cadenat, \& Renaudin, 2011), behavior (e.g., Guo, Zheng, An, \& Peng, 2017; Akar, Mardikyan, \& Dalgic, 2019; Wang, Li, Zhang, Wu, \& Liu, 2020) and engagement (e.g., Brodie, Hollebeek, Juric, \& Ilic, 2011; Van Doorn et al., 2010). Studies on value co-creation in firm-sponsored online communities focused on the enablers more than on the constraints of the process: a systematic review of the literature (from 2000 to 2017), could, for example, find a relatively long list of enablers and, in contrast, only a few constraints (Priharsari, Abedin, \& Mastio, 2020).

This paper adopts a middle managers' perspective and is aimed to assess organizational challenges of business-to-consumer online co-creation for innovation, meaning innovation in a broad sense, which does not refer to its hard, technological dimension (commonly expressed in the realization of new products/new processes 
and in improving the functional and technological content of the offer), but also to the soft one, which finds expression in the creation of new cultural meanings (Borghini \& Carù, 2008), that can lead to an increase in emotional, symbolic and experiential dimensions of value. This "semantic" innovation (Dell'Era, Marchesi, \& Verganti, 2010) is particularly pivotal in the food industry, where low amounts of capital are invested in R\&D, compared to other industries, and companies are still engaged in developing all kinds of innovations needed to keep up with continuously changing consumer preferences (Ciliberti, Carraresi, \& Bröring, 2017). In this context - where true innovation is limited and the lack of meaningful differentiation results in approximately $60 \%-80 \%$ of new food products failing in the market place (Martinez, 2014) - starting a collaboration with consumers, listening to their suggestions, encouraging the reciprocal sharing of knowledge, creativity and ideas (related to new products or, more simply, to new food recipes or new product messages) could offer food companies the opportunity to better assess the needs and preferences of their consumer base, to better (re)define brand meanings and to consequently develop superior value propositions, more relevant to their target (Kemp, 2013).

The focus of this paper will be on the forms of customer community co-creation that take place within the digital environments (social media platforms and company websites), with the aim of exploring, in the light of eight semi-structured interviews with digital and marketing managers involved in different co-creation initiatives in the Italian food industry, the managerial perceptions on intra-organizational challenges to online customer co-creation. Which are the main internal barriers during the implementation process? In what way these barriers could be managed?

To achieve this purpose, the paper is structured as follows: first, there is an overview of the literature in the context of the questions guiding this research: the salient literature on co-creation and its pertinence to online brand communities is shortly analyzed to outline the controversial nature of the same construct of co-creation, before clarifying the view adopted in the present study. Next, the research methodology is described and key findings presented and discussed.

\section{Literature Review}

\subsection{Co-Creation, a Controversial Concept}

Prior research has considered value co-creation from different theoretical perspectives (see, for example, Galvagno and Dalli, 2014, for an exhaustive analysis of the different views and the reciprocal connections). Kambil and his co-authors $(1996,1999)$ first called for the reconsideration of the customer's role in the marketing process while Prahalad and Ramaswamy $(2000,2004)$ popularized this intuition suggesting companies take advantage of co-opting customers' competences (Bendapudi \& Leone, 2003). Under the lens of Service-Dominant logic (S-D logic), Vargo and Lush $(2004,2008)$ outlined that the customer is always a co-creator of value, which is considered as being inherently interactional and phenomenological. In this perspective, the value does not exist per se, but is a function of the use of the exchanged resources, in a particular context and in conjunction with resources provided by other service providers.

Despite the increasing doctrinal attention and the published reviews (e.g., Galvagno \& Dalli, 2014; Voorberg, Bekkers, \& Tummers, 2015; Ranjan \& Read, 2016), the extant literature has not been consolidated into a shared definition of the term co-creation, which still remains "elusive" (Ramaswamy \& Ozcan, 2018, p. 156). Existing reviews (Galvagno \& Dalli, 2014; Ranjan \& Read, 2016) highlight the diverse disciplinary roots of co-creation and scan databases using pre-set search terms to identify the main literature streams: Galvagno and Dalli (2014) used the term "co-creation"; Voorberg et al. (2015) used "co-creation" and "co-production", while Ranjan and Read (2016) added "value-in-use" to these search terms. Chang and Taylor (2016) used "participation", "involvement", "co-production", "crowdsourcing" and "co-creation" in their meta-analysis on customer participation, while Dong and Sivakumar (2017) searched for "participation," "co-production" and "co-creation". Oertzen, Odekerken-Schröder, Brax and Mager (2018) underline that this same diversity of the pre-set search terms used for systematic analyses and the increasing number of conceptual contributions on the interrelations between co-creation and related terms are both symptomatic of the existing and perduring debate on the forms of co-creation. In the following we do not intend, therefore, to synthesize this wide debate but to briefly review some of the main contributions on the topic, to outline controversial issues and clarify the view adopted here.

The first controversial point is related to the distinction between co-creation and co-production. While a part of the doctrine uses these two terms interchangeably (e.g., Normann \& Ramirez, 1993; Gibbert, Leibold, \& Probst, 2002; Chang \& Taylor, 2016; Dong \& Sivakumar, 2017), other contributions outline important elements of difference (Etgar, 2008; Grönroos \& Voima, 2013; Vargo \& Lusch, 2008). For example, in the Service-Dominant perspective (Vargo \& Lusch, 2008; Vargo, 2008), the first expression - co-creation - is used to emphasize the 
collaborative nature of the value creation process (Vargo, 2008); the second one (co-production) is understood as a (subordinate) component of value co-creation and refers to specific activities undertaken by customers, who actively participate in the development of the offer, for example by personally performing, in the self-service mode, some business processes. In this perspective, therefore, the customer is always a co-creator of value and, at times, can be a co-producer. A clear distinction between the two concepts (co-creation and co-production) is also proposed by Ind, Fuller and Trevail $(2012$, p. 7$)$, who define co-creation as "creativity developed together with others". This definition suggests the idea of interaction within a context in order "to evolve, re-define or invent something that is new" (ibidem). In this perspective, the interactive and creative nature of collaboration distinguishes co-creation from co-production, where individuals are engaged, even in marginal forms (such as in the mass customization process), in the production process. In other words, the company co-creates through a partnership with consumers - or other stakeholders - when they are able to exercise a real influence on business choices; if, instead, consumers make a selection among a number of company-defined options (mass-customization), or provide feed-backs on specific business requirements (e.g., product testing) or, even, express their opinions within the marketing research programs carried out by businesses, no real form of co-creation is realized, as it lacks the sense of creativity needed to develop "something new" and, above all, it lacks the bi-directionality of the co-creation process.

Another aspect where convergence is not found in literature is related to the "content" of co-creation and, thus, to the output of the co-creation process. Several contributions (including O'Hern \& Rindfleisch, 2009; Hoyer, Chandy, Dorotic, Krafft, \& Singh, 2010; Füller et al., 2009; Piller, Ihl, \& Vossen, 2011; Guzel at al., 2020) adopt a narrow view of co-creation, which is referred to the new product development process and substantially identified with what literature commonly refers to as "collaborative innovation" (Sawhney, Verona, \& Prandelli, 2005). For example, Piller et al. (2011, p. 21) define co-creation as "an active, creative and social process, based on collaboration between producers and customers, where they are actively involved, taking part in the design of new products or services".

Other contributions define the contents of co-creation in much broader terms, referring to the many forms of customer collaboration in value generation (Zwass, 2010), which can be realized within a broad spectrum of activities: from co-conception of ideas, to co-promotion of products or co-generation of experiences and meanings (Frow, Payne, \& Storbacka, 2011). In a similar perspective, co-creation can be understood as the process by which "mutual value is co-expanded" (Ramaswamy, 2011; Gouillart, 2010; Ramaswamy \& Gouillart, 2010), where value for participating individuals is a function of the experiences they live, resulting from their experience of engagement, as well as from the human, productive and meaningful experiences that result from it.

Seen in these terms, co-creation is not just an organizational opportunity, but a way in which organizations and individuals work together in a "discovery process", which must ensure benefits for individual participants and for the organization: based on this perspective, co-creation can be understood (and will be considered in the present work) as a bi-directional process (Ind et al., 2012), where knowledge and resources (Prahalad \& Ramaswamy, 2004) are exchanged, to improve the whole offering system — not just products and brands, but also the participants' comprehensive experience.

Returning to the previous question (which is the main output of the co-creation process?) we can conclude that this process - based on the capacity of offering engaging and valuable experiences - can lead the enterprise to explore new opportunity spaces and discover nes insights, thanks to the knowledge (co)generated through the interaction. This collaboratively generated knowledge can nurture the creative and innovative potential of the company, allowing it to generate new meanings, to mature new perceptions, to realize those "exploration" processes that can lead to an increase in the value (co)created. The final output of this process can be an innovation, which is not necessarily understood as a new product (from a "functional" point of view) or a new process; we can also refer to the "semantic" aspects of the offering (new meanings of the brand), or to those co-imagination processes (Cova \& Pace, 2006), through which the brand's story is rewritten and re-interpreted, as well as to changes of perceptions and managerial practices (Ramaswamy \& Ozcan, 2014).

\subsection{Online Consumer Communities as a Locus for Co-Creation}

Co-creation is based on a company-to-customer (or other stakeholders) interaction - in both physical and digital environments - which opens up one entity's activities to other entities, "across" the traditional value creational system (Ramaswamy \& Ozcan, 2018, p. 201). The rise of the Internet and the maturation of social media and mobile devices, opened a new world of possibilities of interaction between companies and consumers. Consumers can establish closer relationships with firms and their peers (Nysveen \& Pedersen, 2014) and decide where, when, and how to engage with companies, widely sharing their experiences on the products they use and 
the brands they love, and creating high-quality User-Generated Content (UGC); they can even act as "consumer innovators" (Von Hippel, 2017), thanks to low-cost design tools, largely available via the Internet.

Not surprisingly, customer co-creation is often discussed in the context of online brand communities, where a vast stream of research has flourished. B2C online communities provide a locus where value co-creation may potentially occur. The literature highlights the collective process of value creation (e.g., Schau, Muniz, \& Arnould, 2009; Brodie et al., 2011; Zaglia, 2013; Schembri \& Latimer, 2016), where consumers are found to increasingly perform the role of producers of communal value, by contributing to brand culture, value, identity and offering new ideas or suggestions which would help uncover new products or business opportunities (e.g., Liao, Deschamps, Loures, \& Ramos, 2017; Füller, Jawecki, \& Mühlbacher, 2007; Gensler, Völckner, Liu-Thompkins, \& Wiertz, 2013).

In the digital context—both concerning online communities "hosted" on the company website and social-media platforms - consumers can more actively participate in the company's processes, where they can act as:

- co-communicators, being able to contribute, by sharing information about products and brand narratives (as well as perceptions, judgments, feelings, opinions), to model others' perceptions and behaviors, thus contributing to the (re)definition of the meaning of the brand (McWilliam, 2000; Kozinets, 2002; Wiertz \& de Ruyter, 2007; Nambisan \& Nambisan, 2008);

- co-developers of ideas, solutions, products (Füller et al., 2007; Kristensson \& Magnusson, 2010), being able not only to give their own feedbacks on product prototypes (as, for example, in the so-called beta testing) but also to freely express their expectations, feelings and perceptions about a brand or product, providing their own vision (Parmentier, 2015), which can be an idea, a "solution" or, simply, information about one's own needs.

Accordingly, over the past years, many companies launched online projects (customer ideation contests, open collaborative platforms, etc.), involving their brand communities, with the aim of engaging consumers in value-creating activities, such as brainstorming product ideas or advertising taglines for online campaigns. In these projects, customers participation varied in its intensity, taking many different forms: voting for a TV advertising script (Nespresso) or for the flavor of a new yogurt (Danette Danone) or creating the recipe of a new potato chip snack (San Carlo) based on a list of ingredients. In these examples, the TV script, the flavor or the basic ingredients of a new product had essentially been pre-defined by the company. The consumer's task was, therefore, quite simple and his participation had a strict focus: he was only tasked with testing, validating or refining ideas and concepts generated internally by the company. In other projects, customer co-creation took a different form, allowing a more pro-active (unsolicited) and open (in terms of expressive freedom) participation on behalf of the consumer. For example, Barilla (the Italian leader food company) created in 2009 the collaborative platform "Nel Mulino che vorrei" (literally: In the windmill I would like), an open, online ideas-sharing platform, where customers and brand fan could freely express themselves, disclosing their rational, emotional, creative proposals about products and brand, as a decisive contribution to the generation of new product ideas and to the enrichment of the brand identity (Rossi, 2011). In this platform the company capitalizing on customer "affection" toward the brand and making all the efforts to maintain a high consumer's motivation to contribute-observed consumers periodically return to propose new ideas (or to take part to other activities), succeeding to prolong their involvement over time, though not requiring them to be constantly engaged. Several new valuable ideas emerged over time in this co-creation platform, such as a new line of wheat meal biscuits, a new type of snack, a fully recyclable packaging and the product innovation also triggered process innovation: for example, the idea of producing a new light wheat meal biscuit triggered the development of a new production process for its cooking, namely the steamed-oven cooking (Rossi, 2011; Filieri, 2013; Cova, Fuschillo, \& Pace, 2017).

In the aforementioned examples, customer's participation varied (Figure 1) in duration and expressive freedom: sometimes consumers were just called to respond to specific questions and solicitations coming from the company, other times they were totally free to express their ideas, opinions, feelings, etc. or to create contents without specific constrains (even though in the firm-initiated co-creation, the initial stimulus was necessarily provided by the company). In terms of duration of participation, some co-creation initiatives ran out in a limited period of time, while others extended over time. For example, some collaborative platforms (like myStarbucksidea and Barilla Nel Mulino che vorrei) have been active online for more than ten years, still allowing the owner companies to feed a continuous dialogue with their consumer base, well beyond the lifespan of specific initiatives (like, for example, an online contest). Co-creating companies can use different co-creation initiatives to reach different objectives: Barilla, for example, uses the same online platform to support the process of "idea generation", with the help of its brand community, while at the same time refining ideas or 
simply confirming the insights that have emerged. The former is open to the participation of the entire community of consumers, the latter works as a kind of permanent focus group ("always on" accessible focus group), involving, from time to time, a certain number of consumers, chosen from among 50,000 enthusiasts, willing to provide their own vision on the topics of discussion launched by the company management.

Regardless of typology of customers participation, customer co-creation initiatives are not always success stories (Schultz, 2007; Gambetti \& Graffigna, 2014; Cova, Pace, \& Skålén, 2015). For example, Gambetti and Graffigna (2014) reconstruct a failure case, related to a company-managed online brand community in the soda drink sector, while Cova and his co-authors $(2015,2017)$ document the decline, both quantitative (fewer participants) and qualitative (fewer relevant or applicable ideas) in the brand's fans engagement around the Alfa Romeo community, since company marketers managed the interaction with consumers as if they were salaried workers, while consumers would have expected to be involved in more social and emotional terms.

Why, then, we can ask, are some organizations more successful than others?

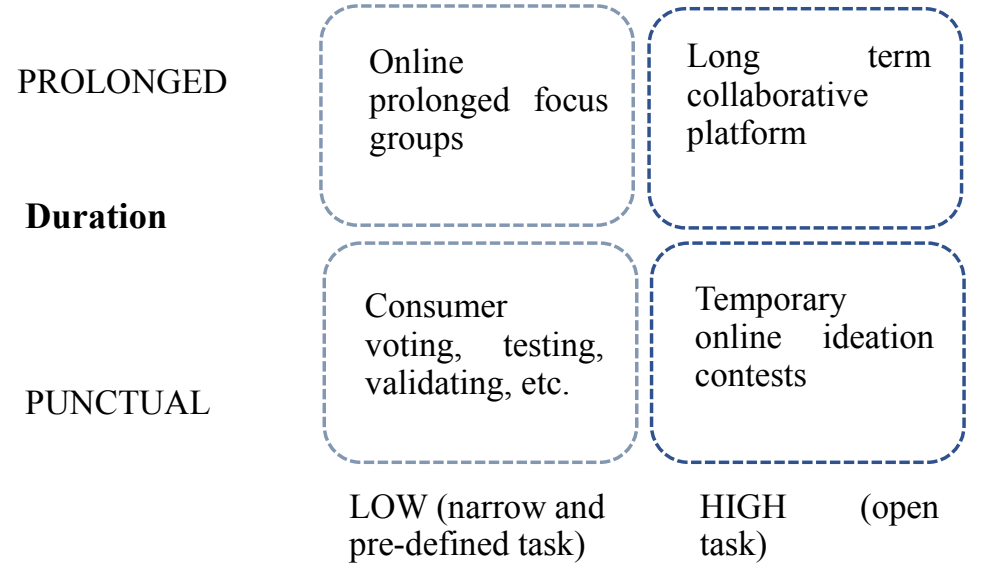

Expressive freedom

Figure 1. Online customer co-creation major initiatives

\subsection{Motivations and Barriers to Customer Co-Creation Online}

In their vast majority, extant studies on customer co-creation in the context of brand communities have almost unilaterally addressed their analysis to the consumer point of view in the creation of value (Cova \& Pace, 2006; Nambisan \& Nambisan, 2008; Cova, Dalli, \& Zwick, 2011; Pongsakornrungsilp \& Schroeder, 2011). Main research streams have focused in particular on different categories of factors (social and personal, extrinsic and intrinsic incentives, etc.) that motivate customers to co-create or co-destroy value (Muniz \& O'Guinn, 2001; Mc Alexander, Schouten, \& Koenig, 2002; Schau et al., 2009; Nambisan \& Baron, 2009; Roberts, Hughes, \& Kertbo, 2014; Black \& Veloutsou, 2017; Quacha \& Thaichon, 2017; Zhang, Lu, Torres, \& Chen, 2018). Other prior studies have analyzed consumers' co-creation behavioral patterns (Chen, Yang, \& Tang, 2013; Habibi, Laroche, \& Richard, 2014; Chou, Lin, \& Huang, 2016) and their identification and engagement (Brodie et al., 2011; Van Doorn et al., 2010), addressing the different outcomes of consumers participation (Nambisan \& Nambisan, 2008; Algesheimer, Dholakia, \& Herrmann, 2005; Habibi et al., 2014; Laroche, Habibi, \& Richard, 2013; Bowen \& Bowen, 2015).

Researchers have also examined, this time from a company's perspective, how to effectively manage the co-creation process and to correctly implement it through the creation of a reciprocally satisfactory experience environment, in order to manage and foster the dialogue with consumers (e.g., Chen et al., 2013; Ramaswamy \& Ozcan, 2014; Cova et al., 2015; Chou et al., 2016; Zhang et al., 2018). Even in this research adopting the company's point of view-suggesting the solutions to be adopted and the antecedents to be created to foster company's ability to attract and retain consumers around its brands and products - the emphasis remains on the community of customers. The objective is to identify the right practices to be adopted to identify, motivate and recruit customers in co-creation processes, satisfying their expectations to maximize their engagement toward co-creative activities (and minimizing the risk of co-destructive ones). Barriers to co-creation are supposed to lie on the borderline between the firm and the community of consumers. This is certainly true, but the "internal" 
perspective should not be overlooked. This is the reason why the present study focuses on the intra-organizational factors that could hinder the implementation process, as perceived by those who are directly involved in it, who can offer a unique point of view on the internal hurdles that may hamper this process.

As mentioned above, a substantive amount of research is focused on motivators to online co-creation (Priharsari et al., 2020), while the literature outlining inhibiting factors is very limited: only a short number of studies (Table 1) explicitly identified some internal deterrents.

Table 1. Literature explicitly referring to internal deterrents in online co-creation

\begin{tabular}{|c|c|c|c|}
\hline Authors & Objectives & Method & Identified Deterrents \\
\hline Hoyer et al. (2010) & $\begin{array}{l}\text { Proposing a comprehensive } \\
\text { framework of the co-creation } \\
\text { process }\end{array}$ & Theoretical paper & $\begin{array}{l}\text { Secrecy concerns, intellectual } \\
\text { property, information overload, } \\
\text { production infeasibility of } \\
\text { consumer-generated ideas }\end{array}$ \\
\hline $\begin{array}{l}\text { Bartl, Fuller, } \\
\text { Muhlbacher \& Ernst } \\
\text { (2012) }\end{array}$ & $\begin{array}{l}\text { Understanding managers' } \\
\text { attitudes toward virtual customer } \\
\text { integration in New Product } \\
\text { Development processes }\end{array}$ & $\begin{array}{l}\text { Quantitative: online questionnaire } \\
\text { on a sample of } 216 \\
\text { German-speaking innovation } \\
\text { managers in the field of consumer } \\
\text { goods and services }\end{array}$ & $\begin{array}{l}\text { Incremental innovations, lack of } \\
\text { secrecy, intellectual property and } \\
\text { the inability of customers to } \\
\text { articulate their requirements }\end{array}$ \\
\hline $\begin{array}{l}\text { Ind, Oriol \& Markovic } \\
\text { (2017) }\end{array}$ & $\begin{array}{l}\text { Investigating the way managers } \\
\text { use co-creation, as a tactical tool or } \\
\text { as a strategic method, outlining the } \\
\text { barrier that can keep brands from } \\
\text { taking advantage of the potential of } \\
\text { co-creation }\end{array}$ & $\begin{array}{l}\text { Qualitative methodology: } 20 \\
\text { semi-structured interviews with } \\
\text { managers (mainly Europeans) in } \\
\text { the field of consumer goods and } \\
\text { services }\end{array}$ & $\begin{array}{l}\text { High uncertainty about the final } \\
\text { outcome, the scope of the } \\
\text { investment, cultural elements, } \\
\text { heavy, hierarchical and rigid } \\
\text { organizational structures }\end{array}$ \\
\hline $\begin{array}{l}\text { Chepurna \& Rialp } \\
\text { Criado (2018) }\end{array}$ & $\begin{array}{l}\text { Identifying the deterrents to } \\
\text { customer participation in the } \\
\text { co-creation process in the } \\
\text { internet-based platforms from the } \\
\text { customers' and companies' point } \\
\text { of view }\end{array}$ & $\begin{array}{l}\text { Qualitative: } 20 \text { semi-structured } \\
\text { interviews with consumers and } \\
\text { marketers }\end{array}$ & $\begin{array}{l}\text { Lack of trust, technology anxiety, } \\
\text { no shared values with brand, } \\
\text { skepticism, inertia, the difficulty of } \\
\text { use, task layout, no offline meeting, } \\
\text { personal availability }\end{array}$ \\
\hline
\end{tabular}

In a study aimed at proposing a comprehensive framework of the co-creation process, Hoyer et al. (2010) identified motivators, stimulators and impediments to co-creation. These impediments are firm-level factors which impact the degree of co-creation: secrecy concerns, questions around the ownership of intellectual property, information overload associated to large volumes of consumer's inputs and production infeasibility of consumer-generated ideas.

Bartl et al. (2012), trying to shed light on managers' attitudes toward virtual customer integration in New Product Development processes, outlined several perceived advantages and disadvantages, including in the latter the risk of generating only incremental innovations, the lack of secrecy, problems regarding intellectual property and the inability of customers to articulate their requirements for new products in a way useful to producers.

Ind et al. (2017) in a study aimed at investigating how co-creation is used (as a tactical tool or as a strategic method) also referred to barriers managers encounter in realizing the potential of co-creation, which they identified with these four issues: high uncertainty about the final outcome, the scope of the investment (time and money needed), cultural elements (fear associated with confidentiality, distrust about customer capability to contribute and confidence in internal knowledge), heavy, hierarchical and rigid cultural organizational structures.

Most recently Chepurna and Rialp Criado (2018) carried out explorative research to identify the deterrents to customer participation in the co-creation process from the customers' and companies' point of view. Once again, the focus was on the deterrents to customer participation not on the obstacles that could emerge from "within" the company during the implementation.

Little research was conducted on the key internal challenges of co-creation in the business-to-consumer context. We, therefore, decided to fill the gap and to explore the intra-organizational challenges perceived by those who are involved in the implementation of co-creation, with the intent to broaden the existing conceptual understanding of the main factors hindering the process, as well as of the practices that can be adopted to best manage them. 


\section{Method}

We adopted a qualitative approach, to flexibly explore participants' experiences (Fawcett et al., 2014), capturing the context of the research at the highest possible richness level (Corbin \& Strauss, 1990). As several researchers have noted (Yin, 2003; Gummesson, 2006), qualitative methods are very useful to generate new understandings of existing phenomena. This research is based on in-depth, semi-structured interviews with middle managers involved in the implementation of customer co-creation, to obtain direct, extensive narrative from the participants in these activities, which would be difficult to gain using quantitative techniques (Bansal \& Corley, 2012). The qualitative approach thus facilitated the rich and in-depth descriptions needed, given the nature of the phenomenon in question, which is both complex and multifaceted (cf. Patton, 2002).

We based the study on a purposive sample of companies (Miles \& Huberman, 1994), selecting information-rich firms, manifesting the phenomenon of interest (Patton, 2002). As aforementioned, we focused on the food sector, which is experiencing a constant increase in competition, the shortening of products' lifecycles and the growing heterogeneity of the customers' needs, with consumers demanding for a greater variety of higher quality products, more closely tailored to their specific needs and health interests (Aguilera, 2006; Fortuin \& Omta, 2009; Martinez, 2014). In this sector, therefore, companies can develop superior value propositions through the collaboration with their consumers (Kemp, 2013).

We identified the suitable companies on the basis of the following criteria: (a) companies with a current engagement in a customer co-creation initiative who had begun experimenting with online co-creation from at least 5 years and could, therefore, capitalize on their experience; (b) a mix of firms, all operating in the food industry, representing organizations of different sizes, Italian firms or branches of global corporations, operating in different geographies. All companies considered are based in Italy because in-depth interviewing, requiring probes and follow-up questions, is more easily conducted in person, also allowing the researcher to capture non-verbal elements, like the tone of voice and similar paralanguage cues (Opdenakker, 2006). The reverse side of the coin is, inevitably, the limited geographical area, due to the time and financial constraints.

We selected different companies (by organization size, demographic and geographic served markets, etc.) but all operating in the food context, to provide a diverse range of cases relevant to a particular industry, to gain as much insight as possible into the phenomenon under examination, through meaningful comparisons. The sectorial and geographical focuses are limitations of the study that we intend to overcome by extending our research to other industries and countries.

To begin, we first carried out a preliminary screening of newspapers and other public online sources, including company web and social pages, to identify focal firms, with long-standing, directly managed initiatives in online consumer co-creation. Subsequently we excluded the companies who managed their initiatives only through the web-based platform of co-creation agencies (like eYeka, Zooppa, etc.). In order to identify informants responsible for cocreation-related activities, we first contacted the selected firms via telephone and negotiated the "access". Anonymity was guaranteed to allow the participants to openly discuss sensitive business information without adding limitations to the research results. For each organization, one "key informant" was recruited, the most experienced manager, who was involved in the co-creation initiative from the very beginning (in Appendix A the profile of interviewed companies is presented).

The use of semi-structured interviews was chosen as it assured that the relevant concepts from the previous literature on co-creation were included in the interview guide, in order to obtain empirical insights on them, while leaving respondents the freedom to talk about their co-creation projects, and thereby allowing the emergence of unexpected issues (Wengraf, 2001). The interviews followed an in-depth, loosely structured approach and involved the use of open-ended questions, with probing questions used by the interviewer to clarify and elicit more details from the participants' initial responses (see Appendix B for the interview guide). The respondents (professionals working closely with co-creation as digital manager or marketing specialists or other, differently named, professional agents charged to introduce and maintain the online co-creation practice) were encouraged to share their experience and perceptions regarding online customer co-creation, as well as the activities that their company engaged in to embrace and tap into the full power of consumer co-creation to sustain innovation. Secondary data such as company reports, press releases, official website and social media, firm's internal documents provided a means to collect background data about the company and to achieve data triangulation (Yin, 2003). All the interviews were personally conducted by the author in 2019 at the businesses location and lasted $100 \mathrm{~min}$ on average. Interviews were audio recorded and transcribed. All transcriptions, along with observational field notes and other available material (reports, documents, etc.) were analyzed and for each organization a case description was written and shared with the interviewees to check for possible errors or 
omissions and to evaluate the validity of our interpretation of "their" perceptions about internal challenges. All the omissions and misinterpretations were thus corrected. The resulting descriptions were analyzed to uncover emerging themes, patterns, concepts and understandings (Patton, 2002) and acted as a source for citations used in illustrating the reported findings.

\section{Findings}

The biggest perceived organizational challenges and main coping strategies are presented, by point, in the following.

\section{- $\quad$ Overcoming managerial inertia}

In the respondents' perception, the most prominent critical point, in the beginning, was related to trying to get the right mindset and an adequate organizational engagement, overcoming all forms of managerial skepticism and inertia.

"In our experience, the biggest initial problem was not related to engaging consumers-who proved to be emotionally linked to the brand and very prone to be involved - but managers" (company G).

"We had to explain to some employees/managers, endowed with professional competences, but used to working with different logics, what co-creation was all about, and how to benefit from it" (company E).

"When I talked about online co-creation, the reactions were not warm. Everyone was afraid that the digital would be a boomerang, because a criticism, even the most innocent, on social media can have a disproportionate echo" (company F).

Embracing co-creation frequently generated a widespread organizational skepticism, mainly attributed to fears of a different nature (e.g., fear of losing control over communication, fear of seeing the secrecy of company information violated, etc.), as well as to the managerial presumption that led to "refuse", or to consider inadequate, creative contributions not internally generated, by virtue of the so called "not-invented-here" syndrome (Katz \& Allen, 1982).

To change the critical attitude and create a more realistic awareness towards co-creation a major communication and educational effort was required to generate adequate co-creation literacy. To better cope with this challenge, some of the companies analyzed decided to start with the launch of pilot projects in order to test the waters and progressively adjust the "sight", by taking in account useful indications before implementing larger-scale initiatives. Measuring pilot project outcomes allowed to identify room for improvement, as well as to communicate progress, providing the organization with clear evidence of the potential of customer co-creation.

"The success of the pilot initiative, besides confirming the existence of groups of consumers, emotionally involved with the brand ... contributed to help the entire company organization to perceive the potential of similar projects" (company E).

"The results of the first project, that we managed with the support of a specialized intermediary to get consumers' feedbacks about testing a new product, made us grasp the potential of collaborating with consumers, inducing us to invest in the creation of our online community" (company A).

"We started with the restyling of our site, which became a blog-website, intending to encourage interaction, sharing of recipes, ideas, advice, with our consumers, to try to create/improve products based on people's requests, without ever losing sight of our core values. The consumers' responses gave us indications on how to continue on this path of openness" (company H).

\section{- $\quad$ Creating and sustaining internal commitment over time}

In addition to pilot projects, other interventions aimed at helping the organization to metabolize the new approach were adopted on the organizational structure. Decentralized cross-functional teams and internal change agents (champions) were the main solutions deployed to create flatter decision structures, a more open culture, and more socialized managers. Two companies reported having formalized organizational roles in place to coordinate their activities. These dedicated entities were put in place (and grew) over time, being well visible on the organization chart, in order to help to concentrate know-how, but their mandate was also to organize and support co-creation, to foster the explicit recognition and organizational legitimacy to allocate critical resources to the project and to act as evangelizers, persuading people to incorporate co-creation into their working methodology.

"A clear signal of the desired change - and of the top management's will to attribute more weight to online co-creation with consumers - was launched through the creation of an internal Digital Team" (company E). 
"We [Digital Media and Communication] assumed a formal role, but also an informal one, acting as evangelizers and trying to persuade our functional managers to incorporate co-creation into the way they worked" (company G).

Though presenting dedicated entities as a focal point of learning, respondents didn't hide that these structures initially seemed to turn out to be a double-edged sword, by engendering a wrong organizational perception ("co-creation is someone else's affair"), thus favoring a sense of disengagement and lowering other business units' attention.

In this sense, a major challenge was related to making the organization consider co-creation not as a task of a single function (even though a new dedicated role had been created), but as a shared responsibility of the whole organization. The problem was therefore related to inspiring people to "engage in" and curiously explore new relations, increasing the level of attention reserved to the dialogue and collaboration with customers. These activities were perceived by respondents as particularly difficult to manage, requiring a big effort (perceived as "bigger than expected"), needed to help the entire structure to "metabolize" the new way of working and one's role within the co-creation process. Those organizations that failed to sustain the internal commitment over time recognized this was the main reason why a project, launched with enthusiasm, slowly languished.

"After the initial enthusiasm, we clearly perceived a strong divergence between the position managers declared before ("Great! From now on I can directly speak with consumers ...") and managers attitude assumed after the beginning ("I do not have enough time to talk with the consumer. It should be a task of the digital team")" (company G).

"Some managers saw the project as an "extra" compared to their daily activities; they considered it as an additional activity for which it was hard to find the time, being already absorbed by routine management. A key issue was finding time ..." (company A).

- Developing absorptive capacity

Companies succeeding in sustaining internal commitment over time could also count on senior management support and revised internal processes, metrics, and incentives to induce initial adoption and subsequent changes. In these terms, besides initial management/employee inertia, another, related, critical issue was perceived by the respondents about internalizing user-generated content, showing high receptiveness of ideas from consumers and ability to transform these ideas into successful co-created products, services, experiences.

With this respect, a first critical issue perceived by the respondents was related to an internal lack of capability to analyze the big amount of data generated through the online dialogue with consumers. In these terms, the use of external partners was a common, critical driver for organizational implementation. In particular, external expertise was required to analyze the sheer volume of user-generated content and to manage the company's social space, ensuring that new insights and emerging market trends were identified and internalized to feed internal processes.

"External digital agencies helped us to make the most of the data. They worked alongside the brand teams - that executed content for test-and-learn objectives-and handled the numbers, trends, and outcomes" (company G).

After providing managers with the necessary external support to "strengthen" their capacity for data analysis, a great effort of time and energy was required to synthesize all the ideas afterwards, understand the big, unlooked-for themes that underpin them and put it in relation with the knowledge base of the firm. The biggest challenge was therefore related to facilitating the development of an adequate "absorption capacity" (Cohen \& Levinthal, 1990; Chandy, Hopstaken, Narasimhan, \& Prabhu, 2006), thus improving the managerial attitude towards the identification, assimilation and exploitation of knowledge that was co-generated in the dialogic interaction.

"We wanted to actively encourage employees other than "gatekeepers" (staff working with consumers) and technical staff to interact with customers and to disseminate this co-created knowledge internally. This is why we introduced new procedures" (company G).

"Somehow we had to force people to listen to customers. To encourage marketing and product development managers to adopt a truly customer-centric perspective, increasing the level of attention they reserved to dialogue with users, we (the digital team) created a monthly newsletter (with the selection of the best ideas generated by our customers) highlighting the most significant points of reflection emerged from the online conversation" (company E). 
Underscoring the need to "really listen to customers" and learning from this interaction, some interviewees outlined the need to invest in feeding the absorption capacity of the organization. In this perspective, their companies realized they needed to introduce new procedures to expand the whole company's commitment "to sense and respond" to consumers' solicitations: an open collaboration platform could generate thousands of entries whose potential for innovation would have been wasted if no one within the organization had the time and energy to take charge of it. A lot of time and energy was needed to grasp the potential of ideas generated by the consumers, recombine knowledge and using it to orchestrate a response, of greater value, to the emerging needs of the market. Some examples of procedures that were set in place to guarantee the company's full commitment were the creation of a monthly internal newsletter focused on the most significant point of reflections emerged from online dialogues with customers as well as periodical reviews involving the whole company. The most effective solution adopted to stimulate a real change in managers' attitude was related to the provision of incentives: to persuade managers, absorbed by their daily routine, to spend time listening to customers and evaluating their ideas, rewards were linked to the accomplishment of specific "missions", like the identification and transfer of consumers' ideas across the boundary of the firm or their utilization in internal projects.

Anchoring the incentive system to the ability shown by management to adopt a real customer-centric perspective proved to be an effective way to manage the discrepancy between declared intentions (what an individual said) and behaviors (what he really did) and to facilitate faster absorptive capacity development (Cohen \& Levinthal, 1990), improving managerial attitudes towards the identification, assimilation, and valorization of co-generated knowledge.

"Co-creation must become part of their routine so we entrust them [brand managers] with a monthly mission: assessing, on a monthly basis, the feasibility of a new solution/idea proposed by one of our customers. The performance of this activity is part of the individual incentive and annual assessment plan. They have to put their face on it" (company E).

\section{- Engaging functional managers in the dialogue and providing adequate feedback}

To persuade the entire management to adopt a "real" customer-centric perspective, some companies called their functional managers to "put their own face on it" being directly involved in the online dialogue with the customers, a typical garrison of the Communication function.

"To increase their engagement, we asked our functional managers to directly provide feedback and interact with customers: in turn, they are called to present themselves in the first person and to illustrate to the community the state of implementation of the ideas that fall within their tasks...Sure, we [the Communication team] have had to intervene frequently on the created contents, to adapt the linguistic register and to maintain a human sound in the communication... but involving other managers in "front-line" activities is another way to obtain their attention" (company A).

"Our CEO was frequently personally involved in dialogue with consumers. He was the first to put his face on it" (company H).

Respondents were aware of the communication effort needed to sustain over time the co-creation process, requiring companies to provide transparent, adequate feedback to the participants and to show their ability to keep their promises. This communication effort (conveyed through the corporate blog, company's official profile on social media, company's website, etc.), was considered essential to gratify emotionally committed consumers who dedicated their time and knowledge to the company and expected in return ongoing and proper feedback but also to sustain interaction, softly soliciting customers' interventions and addressing their contributions. In the respondents' view, the company-customer dialogue could become engaging only when the company succeeded in providing a "vision from within" of the business problems, being, for example, able to explain, in simple terms, the reasons why an idea coming from the world of consumption, while pleasing to many consumers, was not feasible from the point of view of the company. Based on this perspective, a really engaging and open dialogue, required the company to rethink its communication style/register, avoiding the persuasive and blatantly commercial language commonly used in advertising, but also the bureaucratic and technical ones, commonly adopted in internal communication.

\section{- $\quad$ Managing behavioural speed asymmetry}

Despite these efforts, an unforeseen critical point derived from the impossibility to compress, beyond certain limits, the company response time. Many respondents referred to a kind of structural asymmetry of the behavioral speed: talking about food, consumers were very fast in proposing ideas (for new products, new 
flavors, new recipes, other improvements, etc.) and they expected the same speed of (re)action from the company. The company, on the other hand, could not compress beyond certain limits the time needed to carry out its processes.

"We tried to impress more speed of reaction on the part of our Research and Development, at least to provide first "partial" answers, but we still perceived high risk of disappointing consumers' expectations" (company E).

"People expect to be able to handle the interaction as they would do with another individual... Managing co-creation is challenging in the age of impatience" (company G).

Such behavioral speed asymmetry represented - in the respondents' perception - a critical point because waiting time could attenuate consumers' engagement, shying away from the initiative the most impatient consumers.

To manage this risk, two of the participating companies reported they combined long term initiatives with "quick wins". In other words, different co-creation practices were adopted in combination: some (e.g., collaboration platform) aimed at carrying out long term projects (e.g. creating a new product that responds to the "desiderata" expressed by the customers), while others of minor complexity (involving users in less difficult initiatives, like creating a new slogan, suggesting a recipe or the name for a new product, etc.) were used to demonstrate to the consumers, in the short term, their ability to keep promises. These so-called "quick wins" helped co-creating companies to re-ignite interest in the initiative, reinvigorating commitment towards the broader (and long-term) objectives of the project. In this same direction, other companies adopted approaches/platforms of gamification, based on the typical structures and mechanics of games (e.g., points, levels, badges, contests, challenges, missions) to bring about user engagement and improve consumers' experience, contributing to their continued participation. In this way, even long-standing projects could be constantly renewed and refreshed.

\section{- $\quad$ Changing the metrics}

The "time" factor represented a critical element also in another perspective. When co-creation is managed in a strategic perspective, it cannot be evaluated with traditional metrics. A critical element is to make the company reason with other logics, oriented to gather the advantages that can derive from a stable, long time relation with the customer.

"We are talking about developing relationships...that cannot be measured with traditional, short-term indicators" (company E).

For companies declaring that their main goal was to "involve the digital generation, increasing the brand awareness" (like company D) it was relatively simple to identify a metric; for those trying to achieve a more strategic consumer engagement, it was evident the risk of killing the initiative with too rigid performance indicators, which could prevent the trial-and-error learning, essential for capability development.

In these terms - obtaining long term commitment and patient money—strategic mentoring from board members plays an essential role in moving co-creation toward a more strategic perspective (Ind et al., 2017).

\section{- Managing the consumers'functional fixedness}

Another critical point highlighted by some of the respondents is related to the kind of contribution provided by the customers and to the process of selection of ideas. Prior innovation literature outlined that when a company asks users to solve a problem or to propose ideas/concepts for new products there is a risk: their "functional fixedness" can hinder their imagination to propose "radically new" ideas, which conflict with the familiar ones. Poorly managed customer co-creation initiatives can therefore lead companies to obtain only proposals for incremental improvements or "nostalgic" demands for discontinued products.

"Collaboration with customers makes sense, but in fact, we get very few ideas about products from customers. They're more like people who wish for an old campaign product to be re-launched..." (company B)

"Sure, customers can provide us with great ideas, even though they do not always seem to know what they really want. They can suggest us to re-propose a dismissed product because they remember it with nostalgia... But would they really buy it?" (company E)

To address the tendency to nostalgia and access to a wider pool of creativity, co-creating companies invested in the development of differentiated collaborative mechanisms (promoting competitions, online surveys and focus groups, customer engagement in new product development teams, etc.) and, above all, they had to broaden their range of listening, by extending it beyond the narrow confines of the "proprietary" platform, to try to intercept different consumers in the wider digital ecosystem, with the aim of devoting attention to the "weakest signals" 
coming from consumers. Thus, co-creation was implemented more openly by layering multiple platforms to enlarge the scope of interactions and facilitate novel combination and recombination of knowledge from a diverse network of users (and non-users).

"Consumers who interact in our community are predominantly brand fans and in large part are not the same ones we meet on social media, where we can also come across non-consumers and succeed to broaden our range of listening" (company B).

"In addition to the proprietary ones, we regularly use intermediary platforms because we want to feed our creativity" (company F).

Anyway, a common perception was that users were able to propose radically new ideas, as well as incrementally improve existing products.

"We had thousands of requests of incremental improvements but we also found some ideas with a very high innovation potential" (company E).

"We always have to remember that the "next big thing" is not already there, in the form of an idea ready to use and nicely packaged for us: it can emerge when one idea, coming from a customer, triggers further ideas that the firm can build upon" (company C).

In the perception of the respondents, the problem, once again, was not related to consumers' creativity but to companies' absorptive capacity: someone in the organization had to identify, refine and build off consumers' creative input and this result could not be achieved if, as previously stated, procedures, processes and incentive systems were not redefined.

While showing confidence in the consumer's creative (imaginative) capacity, respondents did not seem as confident in consumers ability to identify and select - for example with the online voting mechanism - the most creative and workable ideas.

"We had to introduce several variations to the operating rules of our platform [the voting mechanism] to promote innovations that, despite being sensible in terms of business, did not receive the necessary level of social consensus" (company E).

"The first time [we did a contest], the whole thing - ideation and voting - was entrusted to consumers. The proponents of the ideas sought "support" from friends and relatives through social media. This dynamic, certainly useful to feed word-of-mouth, did not lead us to obtain ideas consistent with our expectations. So, we decided to reduce the weight of social vote and to introduce an expert panel" (company D).

In these terms, companies investing in long term initiatives were aware of the need to consider co-creation as a continuous process of experimentation, adaptation and learning, an endless and dynamic process.

Contrary to our expectations, one of the main obstacles identified in the literature, related to the management of intellectual property, did not emerge with particular evidence in the interviews since the respondents believed to have found-over time, with subsequent "adjustment" processes - the right solutions (the right mix of monetary, intrinsic and social rewards) to avoid the consumer perception of "double exploitation".

In this sense, the clear definition and communication of the rules of participation-which, over time, were modified and updated - was considered as the first form of protection of the reciprocal rights of the company and of consumers.

While the barriers linked to intellectual property were not so highly perceived, the fear of revealing relevant information to the competitors, another main obstacle identified in the literature, was more strongly felt by the companies that adopted co-creation in a strategic perspective. In this case, too, the solutions adopted-though not being perceived as definitive-were the result of the emerging learning process that led some companies to reduce, on the proprietary platform, the visibility of ideas provided by customers, or, in one case (company F), to find a more extreme solution, like entrusting the management of the process to a specialized intermediary (a solution appreciated especially as a way to manage the "demanding nature" of working with consumers).

\section{Discussion}

Businesses can approach the potential of co-creation in a limited way, considering it as a marketing tactical tool, or can frame it in a longer-term perspective, as a key process that can feed a truly collaborative innovation logic.

Adopting such an approach means not only recognizing, beyond rhetoric, that the consumer is a subject with a creative potential that can be enhanced in the process of co-creation, but also strive to create internal and external pre-conditions, needed to feed an effective dialogue and to enhance the company's own potential for co-learning 
and innovation.

From this point of view, we need to avoid a simplistic or deterministic vision of customer co-creation: a profound rethinking of the logics of relationship with the market, as well as of company's procedures, processes, structures and culture, is needed to achieve the expected results. In these terms, when companies decide to invest on co-creation, they must undertake a non-trivial process of metamorphosis, in order to overcome the multiple inertial factors that would tend to refrain them in their traditional modus operandi. The success or failure in the implementation is, therefore, strongly influenced by the quality of the managerial action (Rossi, 2011).

Based on 8 semi-structured interviews with managers involved in co-creation, we explored challenges that organizations face not only when they decide to adopt co-creation but also along with the conduction of the process. In these terms, the inclusion of customers as co-creation partners has evoked distinct challenges, according to the interviewees' statements, which are related to barriers of different nature: organizational, cognitive, temporal and communicative (Table 2).

Table 2. Main challenges (and coping strategies) of co-creation

\begin{tabular}{|c|c|c|}
\hline & Challenge & Practice \\
\hline \multirow[t]{4}{*}{ Organizational } & $\begin{array}{l}\text { Changing the critical attitude, overcoming } \\
\text { all forms of scepticism and resistance }\end{array}$ & Use of pilot projects, communication of success stories \\
\hline & $\begin{array}{l}\text { Creating and sustaining over time the } \\
\text { internal commitment, helping the }\end{array}$ & $\begin{array}{l}\text { Giving a signal of change through the creation of dedicated organizational } \\
\text { structures }\end{array}$ \\
\hline & organization to metabolize the new way of & Revision of internal processes, metrics and incentive systems \\
\hline & $\begin{array}{l}\text { working and one's role within the } \\
\text { co-creation }\end{array}$ & $\begin{array}{l}\text { Involvement of functional managers in customer communication activities } \\
\text { managed through blogs and social media }\end{array}$ \\
\hline \multirow[t]{5}{*}{ Cognitive } & Creating and feeding an absorption & Breaking internal "silos" through the creation of cross-functional teams \\
\hline & capacity & $\begin{array}{l}\text { Provision of external support to strengthen internal capacity for data } \\
\text { analysis }\end{array}$ \\
\hline & & Revision of the incentive system to increase managerial attention \\
\hline & & $\begin{array}{l}\text { Increase in investment on internal communication, to better grasp, share } \\
\text { and channel insights emerging from the dialogue }\end{array}$ \\
\hline & $\begin{array}{l}\text { Avoiding the risk of consumers' functional } \\
\text { fixedness }\end{array}$ & $\begin{array}{l}\text { Adoption of multiple platforms to enlarge the scope of interactions and } \\
\text { facilitate novel combination and recombination of knowledge from a } \\
\text { diverse network of users (and non-users). }\end{array}$ \\
\hline \multirow[t]{3}{*}{ Temporal } & $\begin{array}{l}\text { Managing the speed asymmetry that could } \\
\text { deceive consumers' expectation }\end{array}$ & $\begin{array}{l}\text { Use of different co-creation practices in combination, mixing long term } \\
\text { ones and "quick wins" }\end{array}$ \\
\hline & & $\begin{array}{l}\text { Adoption of a gamification approach to bring about user engagement and } \\
\text { improve consumers' experience }\end{array}$ \\
\hline & $\begin{array}{l}\text { Avoiding the risk of suffocating the } \\
\text { initiative with too rigid performance } \\
\text { indicators }\end{array}$ & Adoption of new metrics focused on long term results \\
\hline Communication & $\begin{array}{l}\text { Managing the internal communication- to } \\
\text { motivate knowledge acquisition and } \\
\text { dissemination-and the external one, to set } \\
\text { the direction of online conversation and to } \\
\text { improve the quality of the experience lived } \\
\text { by the customer }\end{array}$ & $\begin{array}{l}\text { Internal: Creation of inter-functional teams to facilitate communication } \\
\text { between different, involved departments; use of differentiated modes of } \\
\text { internal communication (e.g., newsletter, periodic meetings, in-house } \\
\text { training programs, etc.) to introduce, explain and support the desired } \\
\text { change. External: Providing the right feedback, rewards and solicitations to } \\
\text { customers; managing the dialogue with a more "human" - and less blatantly } \\
\text { commercial - language and tone of voice; sharing the "rules of the game". }\end{array}$ \\
\hline
\end{tabular}

All the identified challenges are in some way of an organizational nature, but we preferred to distinguish those more properly connected to the organizational structure and culture (labeled as "organizational") from the other ones. Moreover, different challenges can be managed through the same practice: for example, investing in internal communication can reduce organizational resistance/skepticism, ensuring internal commitment and, at the same time, facilitate the development of absorption capacity.

With its focus on the managerial perspective of co-creation, this study complements existing literature in two major ways: first of all, extant research generally focused on the challenges related to the initiation of the process; this research tried to widen the observation focus also to the subsequent phase, offering a more diachronic vision; furthermore, the study tried to identify not only the challenges but also the most appropriate coping strategies.

Our results, on one hand, confirm some of the findings of the previous literature, in particular in relation to the 
deterrent role of secrecy concerns (Hoyer et al., 2010; Bartl et al., 2012), information overload (Hoyer et al., 2010) and organizational rigidity (Ind et al., 2017); on the other hand, our results expand previous findings, by identifying additional challenges that, so far, had not been clearly brought to light. We refer, in particular, to the cognitive barriers and to the different practices that can be adopted, also in terms of communication management, to favor the development of an adequate absorption capacity.

At the outset, when co-creation is adopted for the first time, a major communication challenge is enforced to get the right mindset and to provoke a uniform understanding of what co-creation actually means amongst all internal actors, overcoming all forms of organizational resistance or skepticism. To cope with this challenge, interviewees reported having increased their investment in the communication of benefits of co-creation, in particular through the sharing of success stories, associated to pilot projects.

Another critical challenge is related to obtaining - and maintaining over time - the right level of engagement by the entire organization, beyond the directly responsible organizational unit. In this respect, some of the respondents underlined the effort needed to tap into the full power of customer co-creation: a profound revision (of internal processes, metrics, and incentive system) was required, not only to jumpstart to the process but also to effectively implement it, feeding the creation of an adequate absorption capacity. Our study reveals that the few companies which put in place systems to support a more "external" orientation of their staff, for example by changing internal procedures and the incentive system, were the ones which succeeded in making the "assimilation" role more concrete and prominent in the organization, thus facilitating the process of identifying and validating useful ideas provided by customers against internal requirements and aligning them with the organization's overall needs.

Conversely, where these changes were not so marked, where companies did not sufficiently intervene on organizational roles, procedures and incentive systems, co-creation remained mostly as a marketing tool rather than as an instrument for innovation.

For companies approaching co-creation in a strategic perspective, communication played a critical role, not only at the outset of the process, to overcome resistance, but also later, to build feelings of trust, supporting and motivating the people involved in the process. First of all, it was evident that at an internal level companies needed to properly address organizational stakeholders, communicating changed roles, priorities and expected behaviors, in order to motivate knowledge acquisition, sharing and dissemination inside the organization. Adequate communication styles and processes proved to be essential also towards involved customers: clear communication was needed to set direction, reducing the risk of generating wasteful content in the company's perspective but also to keep all participants pleased during the process, providing them with adequate feedback, to reinforce consumers' desire to give their contribution to business choices. As we said earlier, some companies decided to encourage "back-office" personnel to directly interact online with end consumers. For instance, tasks of an R\&D professional was expanded to include explaining to customers, in simple terms, technical reasons for rejecting a user-generated idea or for developing feasible concepts starting from ideas delivered by customers. This level of delegation proved to be an effective way to accrue internal engagement, persuading staff and management to make active efforts to identify and assimilate knowledge contributions coming from the customers.

Our findings help managers understand what are the potential issues to be faced when approaching co-creation and implementing it. Being aware of these factors, a manager should think not only how to increase users' motivation but also how to weaken the negative effect of the potential organizational deterrents. In this perspective, the main problem would not be associated to the risk of consumer's fatigue (Divard, 2010; Rossi, 2011), but to managers' and employees' fatigue (coming from the sensation of increased "time pressure" and the inability to manage the "demanding nature" of working with consumers), which would make it more convenient to consider the consumer as a subject to be activated episodically, "on-demand", by offering rewards or gamification activities, than as a real, long term "co-creating" partner.

\section{Limitations and Further Research}

This study has some limitations which also offer opportunities for future research. First and foremost, the main limitation relates to the exploratory nature of the approach adopted: the study is based on a purposive sample of companies and so the generalizability of the findings may be obtained only once a broader set of perspectives is obtained. Thus, future research could extend the number and diversity of companies analyzed, including firms operating in other businesses, sectors and Countries.

Second, since data collection was based on interviews, the study relies on a double interpretation: first as narrated by the respondents and second through the researcher's analysis of these narratives. This issue of 
"double hermeneutics" (Giddens, 1993), though partially handled through the direct extended observation of online co-creation initiatives managed by the companies under analysis, could be better approached by conducting a netnography of the involved online communities, to better observe the co-creation process from the other side. Limitations also stand in the retrospective sense-making of the interviews, even though much mitigated by extended observations and data triangulation. To further support generalization, survey research may be prescribed after the completion of the research extensions mentioned earlier.

\section{References}

Abbott, W. F., \& Monsen, R. (1979). On the Measurement of Corporate Social Responsibility: Self-Reported Disclosure as Method of Measuring of Corporate Social Involvement. Academy of Management Review, 22, 501-515. https://doi.org/10.2307/255740

Aguilera, J. M. (2006). Seligman lecture 2005 food product engineering: Building the right structures. Journal of the Science Food and Agricolture, 86, 1147-1155. https://doi.org/10.1002/jsfa.2468

Akar, E., Mardikyan, S., \& Dalgic, T. (2019). User roles in online communities and their moderating effect on online community usage intention: an integrated approach. International Journal of Human-Computer Interaction, 35(6), 495. https://doi.org/10.1080/10447318.2018.1465325

Algesheimer, R., Dholakia, U. M., \& Herrmann, A. (2005). The social influence of brand communities: Evidence from European car clubs. Journal of Marketing, 69(3), 19-34. https://doi.org/10.1509/jmkg.69.3.19.66363

Arnould, E. J., Price, L., \& Malshe, A. (2006). Toward a cultural resource-based theory of the customer. In R. F. Lusch \& S. L. Vargo (Eds.), The service-dominant logic of marketing: Dialog, debate and directions (pp. 320-333). London: Routledge.

Bansal, P. T., \& Corley, K. (2012). Publishing in AMJ-Part 7: What's different about qualitative research? Academy of Management Journal, 55(3), 509-513. https://doi.org/10.5465/amj.2012.4003

Bartl, M., Fuller, J., Muhlbacher, H., \& Ernst, H. (2012). A manager's perspective on virtual customer integration in new product development. Journal of Product Innovation Management, 29(6), 1031-1046. https://doi.org/10.1111/j.1540-5885.2012.00946.x

Bendapudi, N., \& Leone, R. P. (2003). Psychological implications of customer participation in co-production. Journal of Marketing, 67(1), 14-28. https://doi.org/10.1509/jmkg.67.1.14.18592

Black, I., \& Veloutsou, C. (2017). Working consumers: Co-creation of brand identity, consumer identity and brand community identity. Journal of Business Research, 70(C), 416-429. https://doi.org/10.1016/j.jbusres.2016.07.012

Bonnemaizon, A., Benoît-Moreau, F., Cadenat, S., \& Renaudin, V. (2011). Client exécutant, assistant marketing, relais ou apporteur de solutions: quel rôle veulent nous faire endosser les enseignes? Paper presented at the 14th Colloque international Etienne Thil sur la Distribution, Roubaix, France.

Borghini, S., \& Carù, A. (2008). Co-creating consumption experiences: An endless innovation. In A. Carù \& K. Tollin (Eds.), Strategic Market Creation (pp. 257-284). Hoboken, New Jersey: Wiley \& Sons.

Bowen, G., \& Bowen, R. (2015). Offline and online brand trust models: Their relevance to social media. Journal of Business and Economics, 6(1), 102-112. https://doi.org/10.15341/jbe(2155-7950)/01.06.2015/010

Brodie, R. J., Hollebeek, L. D., Juric, B., \& Ilic, A. (2011). Customer Engagement: Conceptual Domain, Fundamental Propositions, and Implications for Research. Journal of Service Research, 14(3), 252-271. https://doi.org/10.1177/1094670511411703

Chandy, R., Hopstaken, B., Narasimhan, O., \& Prabhu, J. (2006). From invention to innovation: Conversion ability in product development. Journal of Marketing Research, 43(3), 494-508. https://doi.org/10.1509/jmkr.43.3.494

Chang, W., \& Taylor, S. A. (2016). The effectiveness of customer participation in new productdevelopment: A meta-analysis. Journal of Marketing, 80(1), 47-64. https://doi.org/10.1509/jm.14.0057

Chen, G. L., Yang, S. C., \& Tang, S. M. (2013). Sense of virtual community and knowledge contribution in a P3 virtual community: Motivation and experience. Internet Research, 23(1), 4-26. https://doi.org/10.1108/10662241311295755

Chepurna, M., \& Rialp, C. J. (2018). Identification of barriers to co-create on-line: The perspectives of customers and companies. Journal of Research in Interactive Marketing, 12(4), 452-471. 
https://doi.org/10.1108/JRIM-01-2018-0018

Chou, E. Y., Lin, C., \& Huang, H. (2016). Fairness and devotion go far: Integrating online justice and value co-creation in virtual communities. International Journal of Information Management, 36, 60-72. https://doi.org/10.1016/j.ijinfomgt.2015.09.009

Ciliberti, S., Carraresi, L., \& Bröring, S. (2017). What drives marketing and organizational innovation on the food industry? A comparison between Italy and Germany. Proceedings in System Dynamics and Innovation in Food Networks 2017. http://dx.doi.org/10.18461/pfsd.2017.1719

Cohen, W. M., \& Levinthal, D. A. (1990). Absorptive capacity: A new perspective on learning and innovation. Administrative Science Quarterly, 35(1), 128-142. https://doi.org/10.2307/2393553

Corbin, J. M., \& Strauss, A. (1990). Grounded theory research: Procedures, canons, and evaluative criteria. Qualitative Sociology, 13, 3-21. https://doi.org/10.1007/BF00988593

Costa, A. I. A., Dekker, M., \& Jongen, W. M. F. (2000). Quality function deployment in the food industry: A review. Trends in Food Science \& Technology, 11, 306-314. https://doi.org/10.1016/S0924-2244(01)00002-4

Cova, B., \& Dalli, D. (2007). Community Made: From Consumer Resistance to Tribal Entrepreneurship. Retrieved from https:/www.researchgate.net/

Cova, B., Dalli, D., \& Zwick, D. (2011). Critical perspectives on consumers' role as producers: Broadening the debate on value co-creation in marketing processes. Marketing Theory, 11(3), 231-241. https://doi.org/10.1177/1470593111408171

Cova, B., Fuschillo, G., \& Pace, S. (2017). Le marche siamo noi. Navigare nella cultura del consumo. FrancoAngeli: Milano.

Cova, B., \& Pace, S. (2006). Brand Community of Convenience Product: New Forms of Customer Empowerment-the Case My Nutella the Community. European Journal of Marketing, 40(9-10), 1087-1105. https://doi.org/10.1108/03090560610681023

Cova, B., Pace, S., \& Skålén, P. (2015). Brand volunteering: Value co-creation with unpaid consumers. Marketing Theory, 15(4), 465-485. https://doi.org/10.1177/1470593115568919

Cova, B., \& White, T. (2010). Counter-brand and alter-brand communities: The impact of Web 2.0 on tribal marketing approaches. Journal of Marketing Management, 26(3-4), 256-270. https://doi.org/10.1080/02672570903566276

Dell'Era, C., Marchesi, A., \& Verganti, R. (2010). Mastering Technologies in Design-Driven Innovation. Research Technology Management, 53(2), 12-23. https://doi.org/10.1080/08956308.2010.11657617

Divard, R. (2010). Le Marketing Participatif. Paris: Dunod. https://doi.org/10.3917/dunod.divar.2010.01

Dong, B., \& Sivakumar, K. (2017). Customer participation in services: Domain, scope, and boundaries. Journal of the Academy of Marketing Science, 45(6), 944-965. https://doi.org/10.1007/s11747-017-0524-y

Etgar, M. (2008). A descriptive model of the consumer co-production process. Journal of the Academy of Marketing Science, 36(1), 97-108. https://doi.org/10.1007/s11747-007-0061-1

Fawcett, S. E., Waller, M. A., Miller, J. W., Schwieterman, M. A., Hazen, B. T., \& Overstreet, R. E. (2014). A trail guide to publishing success: Tips on writing influential conceptual, qualitative, and survey research. Journal of Business Logistics, 35(1), 1-16. https://doi.org/10.1111/jbl.12039

Filieri, R. (2013). Consumer co-creation and new product development: A case study in the food industry. Marketing Intelligence \& Planning, 31(1), 40-53. https://doi.org/10.1108/02634501311292911

Fortuin, F. T. J. M., \& Omta, S. W. F. (2009). Innovations drivers and barriers in food processing. British Food Journal, 111, 839-851. https://doi.org/10.1108/00070700910980955

Frow, P., Payne, A., \& Storbacka, K. (2011). Co-Creation: A Typology and Conceptual Framework. In ANZMAC 2011.

Füller, J., Jawecki, G., \& Mühlbacher, H. (2007). Innovation creation by online basketball communities. Journal of Business Research, 60(1), 60-71. https://doi.org/10.1016/j.jbusres.2006.09.019

Füller, J., Mühlbacher, H., Matzler, K., \& Jawecki, G. (2009). Consumer empowerment though internet-based co-creation. Journal of Management Information Systems, 26(3), 71-102. 
https://doi.org/10.2753/MIS0742-1222260303

Galvagno, M., \& Dalli, D. (2014). Theory of value co-creation: A systematic literature review. Managing Service Quality: An International Journal, 24(6) 643-683. https://doi.org/10.1108/MSQ-09-2013-0187

Gambetti, R. C., \& Graffigna, G. (2014). Value co-creation between the 'inside' and the 'outside' of a company: Insights from a brand community failure. Marketing Theory, 15(2), 155-178. https://doi.org/10.1177/1470593114545004

Gensler, S., Völckner, F., Liu-Thompkins, Y., \& Wiertz, C. (2013). Managing brands in the social media $\begin{array}{llll}\text { environment. Journal of } & \text { Interactive }\end{array}$ https://doi.org/10.1016/j.intmar.2013.09.004

Gibbert, M., Leibold, M., \& Probst, G. (2002). Five styles of customer knowledge management and how smart companies use them to create value. European Management Journal, 20(5), 459-469. https://doi.org/10.1016/S0263-2373(02)00101-9

Giddens, A. (1993). New Rules of Sociological Method. Oxford: Blackwell.

Glaser, B. G., \& Strauss, A. L. (1967). The Discovery of Grounded Theory: Strategies for Quantitative Research. Chicago: Aldine Publishing Company.

Gouillart, F. (2010). What the heck is co-creation? Retrieved from http://www.francisgouillart.com

Grönroos, C., \& Voima, P. (2013). Critical service logic: making sense of value creation and co-creation. Journal of the Academy of Marketing Science, 41(2), 133-150. https://doi.org/10.1007/s11747-012-0308-3

Gummesson, E. (2006). Qualitative research in management: Addressing complexity, context and persona. Management Decision, 44(2), 167-179. https://doi.org/10.1108/00251740610650175

Guo, W., Zheng, Q., An, W., \& Peng, W. (2017). User roles and contributions during the new product development process in collaborative innovation communities. Applied Ergonomics, 63(1). https://doi.org/10.1016/j.apergo.2017.04.013

Guzel, M., Sezen, B., \& Alniacik, U. (2020). Drivers and consequences of customer participation into value co-creation: A field experiment. Journal of Product \& Brand Management (ahead-of-print). https://doi.org/10.1108/JPBM-04-2020-2847

Habibi, M. R., Laroche, M., \& Richard, M. O. (2014). Brand communities based in social media: How unique are that? Evidence from two exemplary brand communities. International Journal of Information Management, 34(2), 123-132. https://doi.org/10.1016/j.ijinfomgt.2013.11.010

Hatch, M. J., \& Schultz, M. (2010). Towards a theory of brand co-creation with implications for brand governance. Journal of Brand Management, 17(8), 590-604. https://doi.org/10.1057/bm.2010.14

Hoyer, W. D., Chandy, R., Dorotic, M., Krafft, M., \& Singh, S. S. (2010). Consumer cocreation in new product development. Journal of Service Research, 13(3), 283-296. https://doi.org/10.1177/1094670510375604

Ind, N., Fuller, C., \& Trevail, C. (2012). Brand together: How co-creation generates innovation and re-energizes brands. London: KoganPage.

Ind, N., Iglesias, O., \& Schultz, M. (2013). Building brands together: Emergence and outcomes of co-creation. California Management Review, 55(3), 5-26. https://doi.org/10.1525/cmr.2013.55.3.5

Ind, N., Oriol, I., \& Markovic, S. (2017). The co-creation continuum: from tactical market research tool to strategic collaborative innovation method. Journal of Brand Management, 24, 310-321. https://doi.org/10.1057/s41262-017-0051-7

Kambil, A., Friesen, G. B., \& Sundaram, A. (1999). Co-creation: A New Source of Value. Accenture Outlook, 2. Retrieved from http://kambil.com/wp-content/uploads/PDF/accenture/cocreation2.pdf

Kambil, A., Ginsberg, A., \& Bloch, M. (1996). Re-inventing value propositions. Stern Working Paper, New York University. Retrieved from http://kambil.com/wp-content/uploads/PDF/Value_paper.pdf

Katz, R., \& Allen, T. J. (1982). Investigating the Not Invented Here (NIH) syndrome: A look at the performance, tenure, and communication patterns of $50 \mathrm{R} \& \mathrm{D}$ project groups. R\&D Management, 12(1), 7-20. https://doi.org/10.1111/j.1467-9310.1982.tb00478.x

Kemp, S. E. (2013). Consumers as part of food and beverage industry innovation. In M. G. Martinez (Ed.), Open innovation in the food and beverage industry (pp. 109-138), Cambridge, MA: Woodhead Publishing. 
https://doi.org/10.1533/9780857097248.2.109

Kozinets, R. V. (2002). Can consumers escape the market? Emancipatory illuminations from burning man. Journal of Consumer Research, 29(1), 20-38. https://doi.org/10.1086/339919

Kristensson, P., \& Magnusson, P. (2010). Tuning users' innovativeness during ideation. Creativity and Innovation Management, 19(2), 147-159. https://doi.org/10.1111/j.1467-8691.2010.00552.x

Laroche, M., Habibi, M. R., \& Richard, M. O. (2013). To be or not to be in social media: How brand loyalty is affected by social media? International Journal of Information Management, 33(1), 76-82. https://doi.org/10.1016/j.ijinfomgt.2012.07.003

Liao, Y., Deschamps, F., Loures, E. D. F. R., \& Ramos, L. F. P. (2017). Past, present and future of industry 4.0-A systematic literature review and research agenda proposal. International Journal of Production Research, 55(12), 3609-3629. https://doi.org/10.1080/00207543.2017.1308576

Martinez, M. G. (2014). Co-creation of value by open innovation: Unlocking new sources of competitive advantage. Agribusiness, 30(2), 132-147. https://doi.org/10.1002/agr.21347

McAlexander, J. H., Schouten, J. W., \& Koenig, H. F. (2002). Building brand community. Journal of Marketing, 66(1), 38-54. https://doi.org/10.1509/jmkg.66.1.38.18451

McWilliam, G. (2000). Building stronger brands through online communities. Sloan Management Review, 41(3), $43-54$.

Miles, M. B., \& Huberman, A. M. (1994). Qualitative data analysis: An expanded sourcebook (2nd ed.). Thousand Oaks, CA: Sage.

Muniz, A. M., \& O'Guinn, T. (2001). Brand Community. Journal of Consumer Research, 27(4), 412-432. https://doi.org/10.1086/319618

Nambisan, S., \& Baron, R. (2009). Virtual customer environments: Testing a model of voluntary participation in value co-creation activities. Journal of Product Innovation Management, 26(4), 388-406. https://doi.org/10.1111/j.1540-5885.2009.00667.x

Nambisan, S., \& Nambisan, P. (2008). How to profit from a better virtual customer environment. Sloan Management Review, 49(3), 53-61.

Normann, R., \& Ramirez, R. (1993). From value chain to value constellation: designing interactive strategy. Harvard Business Review, 71, 65-77.

Nysveen, H., \& Pedersen, P. E. (2014), Influences of co-creation on brand experience. International Journal of Market Research, 56(6), 807-832. https://doi.org/10.2501/IJMR-2014-016

O'Hern, M. S., \& Rindfleisch, A. (2009). Customer co-creation: A typology and research agenda. Review of Marketing Research, 6, 84-106. https://doi.org/10.1108/S1548-6435(2009)0000006008

Oertzen, A. S., Odekerken-Schröder, G., Brax, S. A., \& Mager, B. (2018). Co-creating services-conceptual clarification, forms and outcomes. Journal of Service Management, 29(4), 641-679. https://doi.org/10.1108/JOSM-03-2017-0067

Opdenakker, R. (2006). Advantages and disadvantages of four interview techniques in qualitative research. Forum: Qualitative Social Research, 7(4), 1-11. Retrieved from https://pure.tue.nl/ws/files/1948695/Metis202565.pdf

Parmentier, G. (2015). How to innovate with a brand community. Journal of Engineering and Technology Management, 37, 78-89. https://doi.org/10.1016/j.jengtecman.2015.08.001

Patton, M. Q. (2002). Qualitative research and evaluation methods (3rd ed.). Thousand Oaks, CA: Sage Publications.

Payne, A. F., Storbacka, K., \& Frow, P. (2008). Managing the co-creation of value. Journal of the Academy of Marketing Science, 36(1), 83-96. https://doi.org/10.1007/s11747-007-0070-0

Piller, F. T., Ihl, C., \& Vossen, A. (2011). Customer co-creation: open innovation with customers. In V. Wittke \& H. Hanekop (Eds), New Forms of Collaborative Innovation and Production on the Internet (pp. 31-62), Göttingen: Univ.-Verl. Göttingen.

Plé, L, \& Chumpitaz, R. (2010). Not always co-creation: introducing interactional co-destruction of value in Service-Dominant Logic. Journal of Services Marketing, 24(6), 430-437. 
https://doi.org/10.1108/08876041011072546

Pongsakornrungsilp, S., \& Schroeder, J. E. (2011). Understanding value co-creation in a co-consuming brand community. Marketing Theory, 11(3), 303-324. https://doi.org/10.1177/1470593111408178

Prahalad, C. K., \& Ramaswamy, V. (2000). Co-opting customer competence. Harvard Business Review, 78(1), $79-87$.

Prahalad, C. K., \& Ramaswamy, V. (2004). Co-creation experiences: the next practice in value creation. Journal of Interactive Marketing, 18(3), 5-14. https://doi.org/10.1002/dir.20015

Priharsari, D., Abedin, B., \& Mastio, E. (2020). Value co-creation in firm sponsored online communities: What enables, constrains, and shapes value. Internet Research (ahead-of-print). https://doi.org/10.1108/INTR-05-2019-0205

Quacha, S., \& Thaichon, P. (2017). From connoisseur luxury to mass luxury: Value co-creation and codestruction in the online environment. Journal of Business Research, 81, 163-172. https://doi.org/10.1016/j.jbusres.2017.06.015

Ramaswamy, V. (2011). It's about human experiences... and beyond, to co-creation. Industrial Marketing Management, 40(2), 195-196. https://doi.org/10.1016/j.indmarman.2010.06.030

Ramaswamy, V., \& Gouillart, F. (2010). The power of co-creation. New York: Free Press.

Ramaswamy, V., \& Ozcan, K. (2014). The Co-creation Paradigm. Redwood City, CA: Stanford University Press. https://doi.org/10.1515/9780804790758

Ramaswamy, V., \& Ozcan, K. (2018). What is co-creation? An interactional creation framework and its implications for value creation. Journal of Business Research, 84(c), 196-205. https://doi.org/10.1016/j.jbusres.2017.11.027

Ranjan, K. R., \& Read, S. (2016). Value co-creation: Concept and measurement. Journal of the Academy of Marketing Science, 44(3), 290-315. https://doi.org/10.1007/s11747-014-0397-2

Roberts, D., Hughes, M., \& Kertbo, K. (2014). Exploring consumers' motivations to engage in innovation through co-creation activities. European Journal of Marketing, 48(1), 147-169. https://doi.org/10.1108/EJM-12-2010-0637

Rossi, C. (2011). Online consumer communities, collaborative learning and innovation. Measuring Business Excellence, 15(3), 46-62. https://doi.org/10.1108/13683041111161157

Sawhney, M., Verona, G., \& Prandelli, E. (2005). Collaborating to create: The Internet as a platform for customer engagement in product innovation. Journal of Interactive Marketing, 19(4), 4-17. https://doi.org/10.1002/dir.20046

Schau, H. J., Muniz, A. M., \& Arnould, E. J. (2009). How brand community practices create value. Journal of Marketing, 73, 30-51. https://doi.org/10.1509/jmkg.73.5.30

Schembri, S., \& Latimer, L. (2016). Online brand communities: Constructing and coconstructing brand culture. Journal of Marketing Management, 32(7-8), 628-651. https://doi.org/10.1080/0267257X.2015.1117518

Schultz, D. E. (2007). Focus on brand changes rules of engagement. Marketing News, 15(8), 7-8.

Seale, C. (1999). Quality in qualitative research. Qualitative Inquiry, 5(4), 465-478. https://doi.org/10.1177/107780049900500402

van Doorn, J., Lemon, K. N., Mittal, V., Nass, S., Pick, D., Pirner, P., \& Verhoef, P.C. (2010). Customer engagement behavior: theoretical foundations and research directions. Journal of Service Research, 13(3), 253-266. https://doi.org/10.1177/1094670510375599

Vargo, S. L. (2008). Customer integration and value creation. Paradigmatic traps and perspectives. Journal of Service Research, 11(2), 211-215. https://doi.org/10.1177/1094670508324260

Vargo, S. L., \& Lusch, R. F. (2004). Evolving to a new dominant logic of marketing. Journal of Marketing, 68(1), 1-17. https://doi.org/10.1509/jmkg.68.1.1.24036

Vargo, S. L., \& Lusch, R. F. (2008). Service-dominant logic: Continuing the evolution. Academy of Marketing Science, 36, 1-10. https://doi.org/10.1007/s11747-007-0069-6

von Hippel, E. (2017). Free innovation by consumers-how producers can benefit. Research-Technology Management, 60(1), 39-42. https://doi.org/10.1080/08956308.2017.1255055 
Voorberg, W. H., Bekkers, V. J., \& Tummers, L. G. (2015). A systematic review of co-creation and co-production: Embarking on the social innovation journey. Public Management Review, 17(9), 1333-1357. https://doi.org/10.1080/14719037.2014.930505

Wang, Y., Li, C., Zhang, D., Wu, J., \& Liu, Y. (2020). A deeper investigation of different types of core users and their contributions for sustainable innovation in a company-hosted online co-creation community. Journal of Cleaner Production, 256, 1-11. https://doi.org/10.1016/j.jclepro.2020.120397.

Wengraf, T. (2001). Qualitative research interviewing: Biographic narrative and semi-structured methods. Sage, London. https://doi.org/10.4135/9781849209717

Wiertz, C., \& de Ruyter, K. (2007). Beyond the call of duty: Why customers contribute to firm-hosted commercial online communities. Organization Studies, 28(3), 347-376. https://doi.org/10.1177/0170840607076003

Yin, R. K. (2003). Case Study Research: Design and Methods (3rd ed.). Sage, Thousand Oaks.

Zaglia, M. E. (2013). Brand communities embedded in social networks. Journal of Business Research, 66(2), 216-223. https://doi.org/10.1016/j.jbusres.2012.07.015

Zhang, T., Lu, C., Torres, E., \& Chen, P. J. (2018). Engaging customers in value co-creation or co-destruction online. Journal of Services Marketing, 32(1), 57-69. https://doi.org/10.1108/JSM-01-2017-0027

Zwass, V. (2010). Co Creation: Toward a taxonomy and an integrated research perspective. International Journal of Electronic Commerce, 15(1), 11-48. https://doi.org/10.2753/JEC1086-4415150101

\section{Appendix A}

\section{Interviewed companies}

\begin{tabular}{llll}
\hline Company & Number of employees & Interaction platforms adopted & Role of the Interviewee \\
\hline A & $1.000-1499$ & Innovation intermediary, Owned Brand Community, Social media & Communication Manager \\
B & $250-499$ & Corporate Blog, Social media & Brand Manager \\
C & $5.000-9.999$ & Corporate Brand Community, Social media & Community Manager \\
D & $2.000-2.499$ & Corporate website and mini-sites, Social media & Digital Brand Manager \\
E & $5.000-9.999$ & Corporate Open Collaborative Platform, Social Media & Digital Manager \\
F & $250-499$ & Innovation intermediary, social media & Innovation manager \\
G & $250-499$ & Social media, Innovation Intermediary & Digital Media Manager \\
H & $<249$ & Corporate Blog, Social media & Marketing Manager \\
\hline
\end{tabular}

\section{Appendix B}

\section{Interview questionnaire}

\section{THE PROCESS OF CO-CREATION}

When did you launch your first online consumer co-creation initiative? (probe: Why?; What were the main drivers of this decision?)

Can you, please, describe the main consumer co-creation projects your company is involved in?

What roles do online consumer communities play in these projects?

After open-ended, prompt with each of these specific probes:

- Online communities you have set up

- Communities your customers have set up

- Online commercial social media sites

- Blogs

- Other online community (e.g., accessed through an innovation intermediary)

Did you always directly manage co-creation initiatives or rely (relied) on the services of an innovation intermediary? (Why?)

Please, describe what are, in your experience, co-creation main benefits, (un)planned outcomes and main costs/risks 
Can you, please, provide a short definition of consumer co-creation?

\section{THE CHALLENGES OF CO-CREATION}

What was the reaction from your organization when you first engaged in co-creation?

What were the main initial (internal and external) supportive and hindering conditions?

Did you change your approach to co-creation over time? (Why?)

Did the depth and duration of consumers' integration in co-creation processes change over time? (Why?)

Think back to the best ideas/suggestions/opinions coming from consumers...

How did you succeed in incorporating these ideas into new products/concepts or new brand meanings/communication? Please, tell me the story of what happened...

What were the main obstacles you had to face to carry on this process? How did you overcome it?

What are the other interventions/actions adopted to facilitate the co-creation process?

What is your evaluation of the contributions provided by participants? Are consumers' suggestions innovative? In what terms?

Imagine you are able to start a co-creation project from scratch. What would you do differently than in the past? (Why?)

\section{Copyrights}

Copyright for this article is retained by the author, with first publication rights granted to the journal.

This is an open-access article distributed under the terms and conditions of the Creative Commons Attribution license (http://creativecommons.org/licenses/by/4.0/). 